\title{
TYPE OF INFORMATION SOURCE AND THE QUALITY OF KNOWLEDGE IN POST DELIVERY CONTRACEPTION AMONG PREGNANT WOMEN
}

\author{
Noor Azizah \\ School of Health Sciences (STIKES) Muhammadiyah, Kudus
}

\begin{abstract}
BACKGROUND: Good knowledge in contraceptive is important for postpartum women to choose the correct contraceptive for them. It is hypothesized the quality of knowledge in contraceptive vary by types source of information. This study aimed to estimate the assotiation between type of information source and the quality of knowledge in postdelivery contraception among pregnant women.

SUBJECTS AND METHODS: This was a cross-sectional study conducted in Kudus. A sample of 63 pregnant women in third trimester was selected for this study. The dependent variable was knowledge in post delivery contraception. The independent variable was the type of information source. A structured questionnaire was developed to collect the data. The data was analyzed using Odds Ratio and Chi-square.

RESULTS: The quality of knowledge in post delivery contraception varied by the type of information source. The following types of information source increased the likelihood for pregnant women to obtain good knowledge, from the strongest relationship to the weakest relationship: parents $(\mathrm{OR}=7.36 ; 95 \% \mathrm{CI}=2.22$ to $24.38 ; \mathrm{p}<0.001)$, pregnant women class $(\mathrm{OR}=5.19 ; 95 \% \mathrm{CI}=1.57$ to $17.12 ; \mathrm{p}=0.005)$, magazine or newspaper $(\mathrm{OR}=2.28 ; 95 \% \mathrm{CI}=0.64$ to $8.10 ; \mathrm{p}=0.193)$, television $(\mathrm{OR}=$ $1.69 ; 95 \% \mathrm{CI}=0.58$ to $4.89 ; \mathrm{p}=0.326)$, Midwife $(\mathrm{OR}=1.50 ; 95 \% \mathrm{CI}=0.53$ to $4.21 ; \mathrm{p}=0.440)$, and internet $(\mathrm{OR}=1.12 ; 95 \% \mathrm{CI}=0.38$ to 3.28 ; $\mathrm{p}=0.829)$. Friends $(\mathrm{OR}=0.52 ; 95 \% \mathrm{CI}=0.17$ to $1.63 ; \mathrm{p}=0.265)$, facebook $(\mathrm{OR}=0.97 ; 95 \% \mathrm{CI}=0.32$ to $2.99 ; \mathrm{p}=0.971)$, and radio $(\mathrm{OR}=0.80 ; 95 \%$ $\mathrm{CI}=0.26$ to $2.39 ; \mathrm{p}=0.694)$ were types of information source that decreased the likelihood to pregnant women to obtain good knowledge, but they were not statistically significant.

CONCLUSION: Parents and pregnant women class stand out to be two types of information source that strongly increase the likelihood of pregnant women to obtain good knowledge in post-partum contraception, and they are statistically significant.
\end{abstract}

Keywords: type of information source, knowledge, contraception, pregnant women 